\title{
Airway responsiveness to histamine in man: effect of atropine on in vivo and in vitro comparison
}

\author{
JA ROBERTS, IW RODGER, NC THOMSON
}

\begin{abstract}
From the Department of Respiratory Medicine, Western Infirmary, and the Department of Physiology and Pharmacology, University of Strathclyde, Glasgow
\end{abstract}

ABSTRACT Airway responsiveness to histamine in man may be determined by the smooth muscle sensitivity to histamine or to the interaction between vagal nerve input and smooth muscle sensitivity. We have compared in vivo responsiveness to histamine with in vitro smooth muscle sensitivity to histamine in 20 non-asthmatic patients and one asthmatic patient undergoing thoracic surgery. Histamine responsiveness was assessed in the first 10 non-asthmatics without atropine pretreatment, in the second 10 after atropine pretreatment, and in the asthmatic patient both with and without atropine. In vivo responsiveness was also measured in 10 normal subjects and 10 asthmatic patients not undergoing surgery. Results were expressed as the provocation concentration (PC) causing a decrease in $\mathrm{FEV}_{1}$ of $20 \%\left(\mathrm{PC}_{20} \mathrm{FEV}_{1}\right)$ and in specific airways conductance of $35 \%\left(\mathrm{PC}_{35} \mathrm{sGaw}\right)$, and in terms of maximal expiratory flow at $35 \%$ vital capacity, measured from the partial $\left(\mathrm{V}_{35(\mathrm{P})}\right)$ and complete $\left(\mathrm{V}_{35(\mathrm{C})}\right)$ flow volume curves of $35 \%\left(\mathrm{PC}_{35} \mathrm{~V}_{35(\mathrm{P})}\right.$; $\mathrm{PC}_{35} \mathrm{~V}_{35(\mathrm{C})}$ ). In vitro smooth muscle sensitivity to histamine of bronchial tissue obtained at thoracotomy was expressed as the concentration causing a $50 \%$ maximum contraction $\left(\mathrm{EC}_{50}\right)$ and as the maximum tension generated. There was considerable variation between patients in the in vivo responsiveness but a relatively narrow range for in vitro responses. There was no significant correlation between in vivo responsiveness, either with or without atropine pretreatment, and in vitro results. The asthmatic patient showed hyperresponsiveness in vivo but not in vitro. These results suggest that in vitro airway smooth muscle sensitivity to histamine is not the sole determinant of in vivo airway responsiveness and that this lack of relationship is not explained by the influence of vagal nerve input on in vivo measurements. The results in the asthmatic patient suggest that airway hyperresponsiveness may be an in vivo phenomenon which is not related to a primary abnormality of airway smooth muscle.

The bronchoconstrictor response to a stimulus such as histamine requires contraction of airway smooth muscle ${ }^{1}$ which is under nervous, humoral and intrinsic muscular control. ${ }^{2-4}$ Patients with asthma ${ }^{5}$ and chronic obstructive bronchitis ${ }^{67}$ show greater airway responsiveness than normal subjects. The cause of this increased responsiveness is unknown. Histamine produces bronchoconstriction by acting directly on airway smooth muscle $\mathrm{H}_{1}$ receptors $^{89}$ and also possibly reflexly via vagal pathways..$^{10}$ Thus airway hyperresponsiveness to histamine may be due to increased sensitivity of the smooth muscle

Address for correspondence: Dr JA Roberts, Department of Respiratory Medicine, Western Infirmary, Glasgow G11 6NT.

(Reprints will not be available.)

Accepted 19 November 1984 itself, or may be related to an abnormality of the nervous or humoral control (or both) of the airways." If the primary abnormality resides in the smooth muscle then increased in vivo airway responsiveness to histamine would be expected to be associated with enhanced in vitro smooth muscle sensitivity. Alternatively, if in vivo airway responsiveness to histamine is modified by an interaction between vagal nerve input and smooth muscle sensitivity, then a relationship between in vivo and in vitro responses may be apparent only after cholinergic blockade with atropine.

In this study we have examined the sensitivity of smooth muscle in vitro to histamine in an attempt to establish the contribution of smooth muscle in determining in vivo airway responsiveness. The in vivo response to histamine, with and without 
atropine pretreatment, was compared with the in vitro response of isolated strips of bronchi after removal from the same patients.

\section{Methods}

\section{PATIENTS}

Twenty-one patients due to undergo lobectomy or pneumonectomy were studied (table 1). Twenty had operable bronchial carcinoma and one an aspergilloma. One had a history of asthma since childhood and had reversible airflow obstruction. Sixteen were current smokers and all the others except the asthmatic patient ex-smokers. Eight fulfilled the Medical Research Council criteria for chronic bronchitis. ${ }^{12}$ Seven, including the asthmatic patient, were atopic as indicated by a weal response of $2 \mathrm{~mm}$ or more to skinprick testing with one or more of seven common allergens or sources of allergen (house dust, Dermatophagoides pteronnyssinus, cat, dog, feathers, mixed grass pollen, Aspergillus fumigatus); and three of these subjects, including the asthmatic patient, had raised specific IgE levels. Nine patients were having regular drug treatment before surgery. The asthmatic patient did not require regular bronchodilator treatment. Each patient received premedication with papaveretum and hyoscine. Anaesthesia was induced with either Althesin (alphaxalone and alphadolone acetate) or thiopentone sodium and maintained with nitrous oxide and halothane. Various neuromuscular and anaesthetic blocking drugs were given.

Ten non-smoking normal subjects (three of them women) with no history of respiratory disease and in a similar age range (44-67 years) were tested in vivo to establish a normal range for airway responsiveness to histamine (table 2). Three had positive skinprick test responses, but none had increased specific IgE levels.

Ten asthmatic patients (six of them women) in a similar age range (44-75 years) who were not due to undergo surgery were also studied (table 2). Only one smoked cigarettes and one a pipe. Four had positive skinprick test responses and three had raised specific IgE levels. All were taking regular inhaled $\beta_{2}$ adrenoceptor agonists, seven were taking regular inhaled beclomethasone dipropionate, and one patient was taking sodium cromoglycate.

All patients gave informed consent and the experimental protocol was approved by the Western

Table 1 Characteristics of surgical patients

\begin{tabular}{|c|c|c|c|c|c|c|c|c|c|c|}
\hline \multirow[t]{2}{*}{ Patient No } & \multirow{2}{*}{$\begin{array}{l}\text { Age } \\
\text { (y) }\end{array}$} & \multirow[t]{2}{*}{ Sex } & \multirow{2}{*}{$\begin{array}{l}\text { Height } \\
(\mathrm{cm})\end{array}$} & \multicolumn{2}{|l|}{$F E V_{1}$} & \multirow{2}{*}{$\begin{array}{l}V C \\
\text { (\% pred) }\end{array}$} & \multirow{2}{*}{$\begin{array}{l}R V \\
\text { (\% pred) }\end{array}$} & \multirow{2}{*}{$\begin{array}{l}T L C O \\
\text { (\% pred) }\end{array}$} & \multirow[t]{2}{*}{ Atopy } & \multirow{2}{*}{$\begin{array}{l}\text { Current } \\
\text { smoking }\end{array}$} \\
\hline & & & & $(l)$ & (\% pred) & & & & & \\
\hline 1 & 62 & $\mathbf{M}$ & 169 & 1.78 & 61 & 72 & 83 & 90 & - & + \\
\hline 2 & 63 & $\mathbf{M}$ & 181 & 3.05 & 99 & 102 & ND & ND & - & + \\
\hline 3 & 51 & $\mathbf{M}$ & 187 & 4.30 & 110 & 109 & 134 & 73 & + & + \\
\hline 4 & 68 & $\mathbf{M}$ & 173 & 1.65 & 56 & 70 & 85 & 76 & + & - \\
\hline 5 & 54 & $\mathbf{M}$ & 175 & 3.19 & 95 & 99 & 120 & 74 & - & + \\
\hline 6 & 58 & $\mathbf{M}$ & 179 & 1.78 & 53 & 82 & 111 & 99 & - & + \\
\hline 7 & 67 & $\mathbf{M}$ & 169 & 3.37 & 122 & 132 & 98 & 92 & - & - \\
\hline 8 & 62 & $\mathbf{F}$ & 156 & 1.31 & 65 & 73 & 103 & 70 & + & + \\
\hline 9 & 61 & $\mathbf{M}$ & 171 & 2.81 & 93 & 103 & 135 & 82 & - & + \\
\hline 10 & 68 & $\mathbf{M}$ & 163 & 2.18 & 86 & 103 & 144 & 92 & - & + \\
\hline $11^{*}$ & 72 & $\mathbf{M}$ & 173 & 1.95 & 70 & 85 & 109 & 77 & + & - \\
\hline 12 & 52 & $\mathbf{M}$ & 171 & 3.16 & 94 & 92 & 104 & 48 & - & - \\
\hline 13 & 51 & $\mathbf{M}$ & 176 & 2.52 & 72 & 83 & 90 & 97 & - & - \\
\hline 14 & 55 & $\mathbf{M}$ & 171 & 1.78 & 57 & 64 & 106 & 119 & + & + \\
\hline 15 & 53 & $\mathbf{F}$ & 165 & 2.69 & 109 & 105 & 83 & 105 & - & - \\
\hline 16 & 62 & $\mathbf{M}$ & 173 & 3.06 & 98 & 101 & 116 & 69 & + & + \\
\hline 17 & 53 & $\mathbf{M}$ & 185 & 4.70 & 126 & 129 & 108 & 73 & + & - \\
\hline 18 & 60 & $\mathbf{F}$ & 158 & 1.71 & 87 & 88 & 94 & 117 & - & + \\
\hline 19 & 63 & $\mathbf{M}$ & 163 & 2.30 & 82 & 76 & 82 & 89 & - & - \\
\hline 20 & 64 & $\mathbf{F}$ & 165 & 1.95 & 94 & 85 & 154 & 84 & - & + \\
\hline 21 & 61 & $\mathbf{F}$ & 160 & 1.81 & 88 & 89 & 138 & 115 & - & + \\
\hline
\end{tabular}

*Asthmatic patient.

FEV - forced expiratory volume in one second; VC—vital capacity; RV—residual volume; TLCO—transfer factor for carbon monoxide ND-not done.

Table 2 Characteristics of normal subjects and asthmatic patients (means with standard deviations in parentheses)

\begin{tabular}{|c|c|c|c|c|c|}
\hline & \multirow[t]{2}{*}{ Age (y) } & \multirow[t]{2}{*}{ Height $(\mathrm{cm})$} & \multicolumn{2}{|l|}{$F E V_{1}$} & \multirow[t]{2}{*}{$V C$ (\% pred) } \\
\hline & & & (l) & (\% pred) & \\
\hline $\begin{array}{l}\text { Normal }(n=10) \\
\text { Asthmatic }(n=10)\end{array}$ & $\begin{array}{l}53(8) \\
60(9)\end{array}$ & $\begin{array}{l}171(9) \\
165(8)\end{array}$ & $\begin{array}{l}2.96(0.8) \\
1.86(0.7)\end{array}$ & $\begin{array}{r}112\left(\begin{array}{l}14) \\
75\end{array}(26)\right.\end{array}$ & $\begin{array}{r}101(15) \\
88(14)\end{array}$ \\
\hline
\end{tabular}


Infirmary ethical committee.

\section{IN VIVO MEASUREMENTS}

Airway resistance and thoracic gas volume was measured in a constant volume body plethysmograph (Fenyves and Gut) by the methods of DuBois et al. ${ }^{13}$ The results were expressed as specific airway conductance (sGaw), the reciprocal of airway resistance per litre of thoracic gas volume. The mean of eight values recorded was taken as sGaw. Partial and complete expiratory flow-volume (PEFV and CEFV) curves were obtained with a heated pneumotachograph with flow integration, and recorded on an X-Y recorder (Hewlett-Packard $7041 \mathrm{~A})$. The flow volume curves were performed in the following manner. After a period of normal tidal breathing each patient expired maximally from end tidal inspiratory volume to residual volume (RV) to obtain the PEFV curve. When RV was reached the patient inspired to total lung capacity (TLC) and expired maximally to RV to obtain the CEFV curve. From the CEFV curve the forced expiratory volume in one second $\left(F E V_{1}\right)$ and forced vital capacity (FVC) were obtained. The volume corresponding to $65 \%$ below total lung capacity (TLC) was obtained from the mean FVC of at least five baseline curves. Maximum expiratory flows at this lung volume were measured from the partial $\left(\mathrm{V}_{35(\mathrm{P})}\right)$ and complete $\left(\mathrm{V}_{35(\mathrm{C})}\right)$ flow-volume curves for baseline and subsequent curves - that is, curves were matched at TLC for comparison of flow rates. Body plethysmographic measurements always preceded flowvolume recordings.

Histamine inhalation tests were carried out with a modification of the method described by Cockcroft et al..$^{514} 15$ Aerosols were generated with the same Wright nebuliser by air at $50 \mathrm{lb} / \mathrm{in}^{2}(345 \mathrm{kPa})$ at a flow rate of $81 / \mathrm{min}$ to give an output of $0.15 \mathrm{ml}$ min. Patients wore a noseclip and inhaled the aerosols by tidal breathing through a loose fitting facemask. Buffered normal saline was inhaled first, followed by doubling concentrations of phosphate buffered histamine $(2-64 \mathrm{mg} / \mathrm{ml}$ for non-asthmatic patients and $0.06-4 \mathrm{mg} / \mathrm{ml}$ for asthmatic patients). Each inhalation was for 2 minutes at 10 minute intervals. Before the first inhalation eight $\mathrm{sGaw}$ and five PEFV and CEFV curves were recorded. From 1.5 minutes after each inhalation responses were measured by obtaining eight sGaw and two PEFV and CEFV curves. Inhalations were continued until the $\mathrm{FEV}_{1}$ had fallen by $20 \%$ or more or the maximum concentration had been administered. In 11 of the patients (Nos 11-21) who were due to undergo thoracotomy, histamine responsiveness was measured after pretreatment with atropine. After baseline measurements had been made atropine sulphate $(5 \mathrm{mg} / \mathrm{ml})$ was inhaled from the same Wright nebuliser for 5 minutes. Thirty minutes after inhalation eight sGaw and three PEFV and CEFV curves were recorded, after which a histamine inhalation test was performed.

Log-dose response curves were plotted and results expressed as the provocation concentration causing a $20 \%$ decrease in $\mathrm{FEV}_{1}\left(\mathrm{PC}_{20} \mathrm{FEV}_{1}\right)$, a $35 \%$ fall in sGaw $\left(\mathrm{PC}_{35} \mathrm{sGaw}\right)$, a $35 \%$ fall in $\mathrm{V}_{35(\mathrm{P})}$ $\left(\mathrm{PC}_{35} \mathrm{~V}_{35(\mathrm{P})}\right)$, and a $35 \%$ fall in $\mathrm{V}_{35(\mathrm{C})}\left(\mathrm{PC}_{35(\mathrm{P})} \mathrm{V}_{35(\mathrm{C})}\right)$. If the appropriate percentage fall was not observed even after inhalation of the maximum concentration the provocation concentration is shown as $>64$ $\mathrm{mg} / \mathrm{ml}$.

In the surgical group routine preoperative pulmonary function tests were performed: Spirometry was measured on a water sealed spirometer (Godart); static lung volumes were determined by the helium dilution technique; and single breath transfer factor for carbon monoxide (TLCO) was estimated by the method of Ogilvie et al. ${ }^{16}$ Predicted normal values were taken from Cotes. ${ }^{17}$

\section{IN VITRO MEASUREMENTS}

Bronchial tissue was obtained immediately after removal at thoracotomy. Samples from second to sixth order bronchi were dissected from macroscopically normal tissue and then maintained overnight at $4^{\circ} \mathrm{C}$ in well oxygenated Krebs-Henseleit solution of

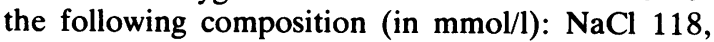
$\mathrm{KCl} 4.7, \mathrm{MgSO}_{4} 1.2, \mathrm{KH}_{2} \mathrm{PO}_{4} 1.2, \mathrm{CaCl}_{2} 2.5$, $\mathrm{NaHCO}_{3} 25$, glucose 11.7. The next day rings of bronchi were dissected out and sectioned. These strips of tissue were then suspended under a resting tension of $1.5-2.0 \mathrm{~g}$ in $20 \mathrm{ml}$ organ baths containing Krebs-Henseleit solution at $37^{\circ} \mathrm{C}$ bubbled with $5 \%$ carbon dioxide in oxygen. After 60 minutes equilibration tissues were washed three times. Change in isometric tension was measured by Grass force displacement transducers (FTO3C) and recorded on a Grass (model 7) polygraph.

The normality of the bronchial strips and reproducibility of their response to histamine was assessed by adding histamine $(10 \mu \mathrm{mol} / \mathrm{l})$ on two separate occasions 30 minutes apart. A cumulative concentration-response study was carried out by adding increasing concentrations of histamine from 0.1 to $400 \mu \mathrm{mol} / \mathrm{l}$ from each addition of histamine being given while the preceding was having its peak effect. The concentration of histamine producing $20 \%\left(\mathrm{EC}_{20}\right)$ and $50 \%\left(\mathrm{EC}_{50}\right)$ of the maximal contraction was calculated. The maximum tension generated by each strip was determined and expressed in $\mathrm{g}$ tension per $\mathrm{mg}$ wet weight of tissue (tissue weight was measured at the end of each experiment). 


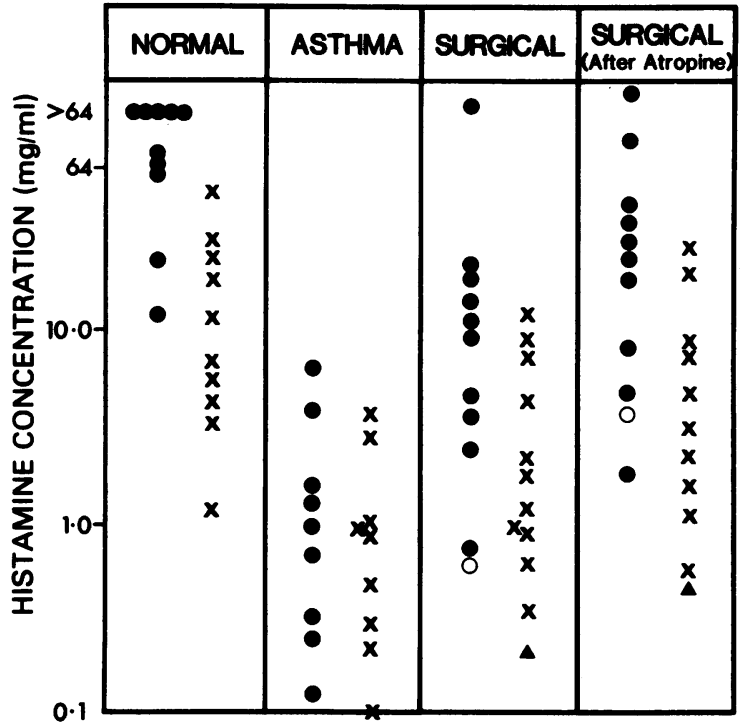

Fig 1 Airway responsiveness to inhaled histamine in normal subjects $(n=10)$, non-surgical asthmatic patients $(n=10)$, surgical patients who did not receive pretreatment with atropine $(n=11)$, and surgical patients pretreated with atropine $(n=11)$. There is one asthmatic patient $(O, \Delta)$ who underwent thoracic surgery. Results are expressed as the provocation concentration (PC) causing a decrease in one second forced expiratory volume of $20 \%$ $\left(P C_{20} F E V,-\right)$ and in specific airways conductance of $35 \%$ $\left(P C_{35} s G a w-x\right)$.

From two to six bronchial strips from each patient were tested to obtain mean values for $\mathrm{EC}_{20}, \mathrm{EC}_{50}$, and maximum tension generated.

\section{STATISTICAL ANALYSIS}

Mean values of baseline $\mathrm{FEV}_{1}$ and sGaw for the groups were compared by means of Student's unpaired $t$ test. Comparison of in vivo and in vitro results was by calculation of correlation coefficients from linear regression by the method of least squares analysis. PC results were analysed after natural logarithm transformation. A $p$ value of $<0.05$ was taken as the limit of statistical significance.

\section{Results}

IN VIVO

Airway responsiveness to histamine varied between and within the patient groups (figure 1). The asthmatic patients were the most responsive, the nonsmoking controls the least responsive. The results of the patients undergoing surgery fell between those of these two groups. The asthmatic patient undergoing thoracotomy (was the most responsive of the surgical group) and within the range determined for the non-surgical asthmatic patients.

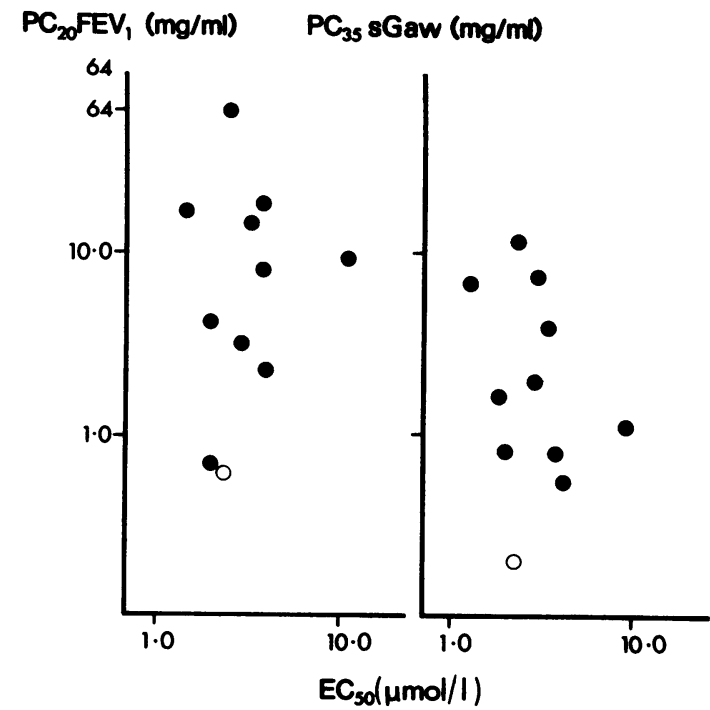

Fig 2 Comparison of in vivo airway responsiveness to histamine expressed as $P C_{20} F E V_{1}$ and $P C_{35}$ sGaw with in vitro smooth muscle sensitivity to histamine expressed as the concentration that produced a $50 \%\left(E C_{50}\right)$ maximal contraction. Left hand panel: $P C_{20} F E V_{1}$ against $E C_{50}$ $(r=0.2 ; p>0.05)$. Right hand panel: $P C_{35}$ sGaw against $E C_{s 0}(r=0.12 ; p>0.05)$. O-asthmatic patient.

The mean baseline FEV 1 expressed as a percentage of the predicted value was significantly higher in the non-smoking controls $(112 \%)$ than in the other groups (table 2). There was no significant dif-

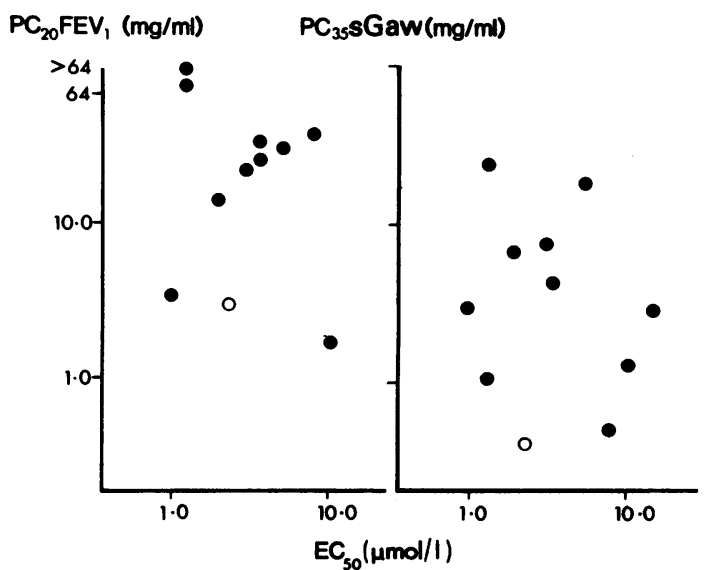

Fig 3 Comparison of in vivo airway responsiveness to histamine after atrophine pretreatment expressed as $P C_{20} F E V_{1}$ and $P C_{35}$ sGaw with in vitro smooth muscle sensitivity to histamine expressed as $E C_{5 \sigma}$ Left hand panel: $P C_{20} F E V$ against $E C_{50}(r=-0.21 ; p>0.05)$. Right hand panel: $P C_{35}$ sGaw against $E C_{50}(r=-0.27 ; p>0.05)$. $\mathrm{O}$-asthmatic patient. 
ference between the asthmatic patients $(75 \%)$ and the surgical patients who did or did not receive pretreatment with atropine $(84 \%$ and $75 \%$ respectively). Atropine produced significant increases in FEV $_{1}\left(7.3\right.$ (SD 4.5\%)), sGaw (112\% (84\%)), $\dot{\mathrm{V}}_{35(\mathrm{P})}$ $(55 \%(28 \%))$, and $V_{35}(32 \%(41 \%))$. The postatropine baseline $\mathrm{FEV}_{1}(82.0 \pm 17)$ was, however, still significantly lower than that of the non-smoking controls and was not significantly different from the other two groups.

In the surgical group not pretreated with atropine baseline $\mathrm{FEV}_{1}$ (percentage predicted) correlated with $\mathrm{PC}_{20} \mathrm{FEV}_{1}(\mathrm{r}=0.66)$ and $\mathrm{PC}_{35} \dot{\mathrm{V}}_{35(\mathrm{C})}(\mathrm{r}=0.62)$ but not with $\mathrm{PC}_{35} \dot{\mathrm{V}}_{35(\mathrm{P})}(\mathrm{r}=0.57)$ or $\mathrm{PC}_{35} \mathrm{sGaw}(\mathrm{r}=$ 0.08 ). There was no significant correlation between baseline $F E V_{1}$ and in vivo measurements of airway responsiveness to histamine in the other study groups. For example, the correlation coefficients for the non-surgical asthmatic patients were 0.01 for $\mathrm{PC}_{20} \mathrm{FEV}_{1}$ and $\mathrm{PC}_{35} \mathrm{sGaw},-0.13$ for $\mathrm{PC}_{35} \dot{\mathrm{V}}_{35(\mathrm{P})}$, and 0.19 for $\mathrm{PC}_{35} \dot{\mathrm{V}}_{35(\mathrm{C})}$.

\section{IN VITRO}

$\mathrm{EC}_{50}$ values for the bronchial strips from individual patients for repeat studies of histamine were reproducible. There were relatively small differences in the sensitivity to histamine of bronchial strips between patients, with a mean (SEM) $\mathrm{EC}_{50}$ value $\left( \pm\right.$ SEM) from all preparations of $4.0(0.7) \times 10^{-6}$ $\mu \mathrm{mol} / \mathrm{l}$ and a range of $1.0-14.0 \mu \mathrm{mol} / \mathrm{l}$. The mean maximum tension generated was 13.8 (1.6) (range $4.2-30.3) \mathrm{g} / \mathrm{mg}$ wet weight.

\section{COMPARISON OF IN VIVO AND IN VITRO RESPONSIVENESS TO HISTAMINE}

There was no significant correlation between any of the measurements of in vivo and in vitro responsiveness to histamine in either of the surgical groups. The lack of relationship of $\mathrm{PC}_{20} \mathrm{FEV}_{1}$ and $\mathrm{PC}_{35}$ sGaw with $\mathrm{EC}_{50}$ is illustrated for the surgical patients who did not receive pretreatment with atropine in figure 2 , and for those who did in figure 3.

The asthmatic patient who underwent surgery did not exhibit increased in vitro smooth muscle responsiveness to histamine $\left(\mathrm{EC}_{50} 2.3 \mu \mathrm{mol} / \mathrm{l}\right.$; maximum tension generated $18.4 \mathrm{~g} / \mathrm{mg}$ wet weight).

\section{Discussion}

In this study of 41 subjects we found a 1000 fold variation in airway responsiveness to histamine. The surgical patients, from whom bronchial tissue was obtained, were more responsive than non-smoking normal subjects of a similar age, but less responsive than the asthmatic patients. Cigarette smoking, chronic bronchitis, and airflow obstruction may all have contributed to the increase in responsiveness in the surgical group. Cigarette smoking has been associated with increased non-specific airway responsiveness in symptom free subjects without airflow obstruction, ${ }^{18}$ though this finding has not been confirmed by others. ${ }^{19}$ Eight patients had chronic bronchitis, which has been shown to be related to hyperresponsiveness both in those with $^{672021}$ and in those without airflow obstruction. ${ }^{22}$ In the surgical group there was a significant relationship between baseline lung function and $\mathrm{PC}_{20} \mathrm{FEV}_{1}$, but this was not true for the normal subjects or for the asthmatic patients. This suggests that baseline airway calibre may be a more important determinant of airway responsiveness in smokers than in patients with asthma.

We do not know whether the presence of a bronchial neoplasm has any effect on airway responsiveness; but a comparison of responsiveness, made by Bahous and coworkers, ${ }^{21}$ in patients similar to ours but without a neoplasm showed a range of airway responsiveness similar to ours.

In this study there was no significant relationship between in vivo airway responsiveness to histamine and in vitro measurements of smooth muscle responsiveness. In vitro measurements were made on tissues which had been washed thoroughly, stored overnight in fresh oxygenated saline at low temperature, and washed thoroughly again before testing. This procedure should have removed all intraoperative medication ${ }^{23}$ that might otherwise have affected the results. Possibly in vitro responsiveness of human smooth muscle changes after removal at thoracotomy, either spontaneously, as has been shown to occur in canine tracheal smooth muscle from ozone treated dogs ${ }^{24}$ or as a result of frequent washing. Brink et $a l,{ }^{25}$ however, found no difference in the sensitivity to histamine of fresh and stored human airway smooth muscle. Since in vitro bronchial strips have no functionally active neural input, the presence of differing degrees of vagal tone in vivo might obscure any relationship between in vivo and in vitro sensitivity. Inhaled histamine is thought to produce a response through a direct action on smooth muscle ${ }^{189}$ and via a nervous reflex mediated via vagal pathways. ${ }^{10}$ By pretreating patients with atropine at a dose which has been shown to decrease the response to methacholine by two log units ${ }^{26}$ any vagal influence which might have confounded a relationship between in vivo and in vitro measurement should have been minimised. Such atropine pretreatment, however, did not enhance the relationship between in vivo and in vitro measurements.

In a previous study comparing in vivo and in vitro responses to histamine in human airways ${ }^{27}$ the $\mathrm{FEV}_{1}$ 
only was used to measure in vivo responsiveness. Because lower doses of inhaled histamine were administered, $\mathrm{PC}_{20} \mathrm{FEV}_{1}$ values were obtained in only five of the 14 patients and $\mathrm{PC}_{10} \mathrm{FEV}_{1}$ in four more. Patients were not pretreated with atropine. Our study confirms and extends the conclusion of this limited study that no relationship exists between in vivo and in vitro measurements, and the findings of a similar study by our group using methacholine as an agonist. ${ }^{15}$

Thus we have shown that, with histamine as an agonist, no relationship exists between in vivo and in vitro responsiveness of the airways, and that modifying the effect of vagal input to smooth muscle does not explain this lack of relationship. The measurements of in vivo airway responsiveness are likely to be the result of a complex interaction between technical, physiological, and pathological factors. ${ }^{14}$

A common feature of asthma is the increased airway responsiveness to varied stimuli. This appears to be non-specific for several triggers since in a given individual with asthma the airway response to one stimulus usually correlates well with that to another. Individuals highly sensitive to histamine are also generally more sensitive to methacholine, ${ }^{28}$ prostaglandin $\mathrm{F}_{2 \alpha}{ }^{29}$ cold air, ${ }^{30}$ and exercise..$^{31}$ One mechanism which could explain this non-specific hyperresponsiveness would be an abnormality in airway smooth muscle. " In vitro hyperresponsiveness of airway smooth muscle could be reflected in a lower $\mathrm{EC}_{50}$ value or an increase in the maximum tension generated by each smooth muscle strip, or both. In this study, however, the one asthmatic patient undergoing surgery showed the expected in vivo hyperresponsiveness to histamine but did not show increased in vitro responsiveness as assessed by $\mathrm{EC}_{50}$ or maximum tension generated. Since the maximum tension generated but not the $\mathrm{EC}_{50}$ could be affected by the quantity of smooth muscle present in each strip, it is possible that by chance there was less smooth muscle in the bronchial strip from the asthmatic patient, and that this was masking a real increase in maximum tension generated. To try to overcome this problem the maximum tension generated was expressed per unit mass of tissue and this failed to alter the conclusion reached. The size and number of smooth muscle cells present in each bronchial strip would have to be determined accurately before a defect in airway smooth muscle function as a cause of airway hyperresponsiveness could be completely ruled out.

In a similar study using methacholine as an agonist, a patient who had features of asthma, including in vivo airway hyperresponsiveness, did not show increased in vitro smooth muscle responsiveness. ${ }^{15}$ Other studies have examined in vitro sensitivity of human bronchial smooth muscle without comparing it to in vivo responsiveness. ${ }^{32-34}$ Dahlen and coworkers $^{32}$ examined bronchial strips, obtained at thoracotomy for bronchial carcinoma, from two patient with asthma who were allergic to birch pollen and found that the bronchial strips from these patients were no more sensitive to histamine or leukotrienes than were strips from non-asthmatic subjects. A study of postmortem tissue from three asthmatic patients who died during acute asthmatic attacks showed no difference between the sensitivity of the asthmatic airway and that of bronchi obtained from normal subjects when both histamine and carbachol were used as agonists. ${ }^{33}$ More recently Schellenberg and Foster ${ }^{34}$ reported that bronchial smooth muscle obtained from an asthmatic patient with a carcinoid tumour did not show increased in vitro responses to leukotrienes or methacholine. The tissue was hyperresponsive to histamine, however, although the authors were unclear about whether this was related to the presence of the carcinoid tumour. Although in vitro studies on tissue from asthmatic patients are rare, the evidence obtained so far suggests that smooth muscle responsiveness is not increased in asthmatic patients with hyperreactive airways. Thus airway hyperresponsiveness may be an in vivo phenomenon not related to a primary abnormality of airway smooth muscle.

We wish to thank Mr MA Turner and Mr A Faichney, cardiothoracic surgeons at the Western Infirmary, for allowing us access to their patients. This work was supported by Fisons Ltd, the Asthma Research Council, and the Wellcome Trust, to which we are grateful.

\section{References}

1 Hawkins DF, Schild HO. The action of drugs on isolated human bronchial chains. $\mathrm{Br} J$ Pharmacol 1951;6:347-55.

2 Widdicombe JG. Regulation of tracheobronchial smooth muscle. Physiol Rev 1963;43:1-37.

3 Richardson JB. Nerve supply to the lungs. Am Rev Respir Dis 1979;119:785-802.

4 Davis C, Kannan MS, Jones T, Daniel EE. Control of human airway smooth muscle: in vitro studies. J Appl Physiol 1982;43:1-37.

5 Cookcroft DW, Killian DN, Mellon JJA, Hargreave FE. Bronchial reactivity to inhaled histamine: a method and clinical survey. Clin Allergy 1977;7:23543.

6 Oppenheimer EA, Rigatto M, Fletcher CM. Airway obstruction before and after isoprenaline, histamine and prednisolone in patients with chronic obstructive bronchitis. Lancet 1968;i:552-7.

7 Laitinen LAI. Histamine and methacholine challenge in the testing of bronchial reactivity. Scand J Respir Dis 
$1974 ; 86$, suppl: $1-46$.

8 Nogrady SG, Bevan C. Inhaled antihistaminesbronchodilation and effects on histamine and methacholine-induced bronchoconstriction. Thorax 1978;33:700-4.

9 Thomson NC, Kerr JW. Effect of inhaled $\mathrm{H}_{1}$ and $\mathrm{H}_{2}$ receptor antagonists in normal and asthmatic subjects. Thorax 1980;35:428-34.

10 Simonsson BG, Jacobs FM, Nadel JA. Role of autonomic nervous system and the cough reflex in the increased responsiveness of airways in patients with obstructive airways disease. J Clin Invest 1967; 46: $1812-8$.

11 Thomson NC. Neurogenic and myogenic mechanisms of non-specific bronchial hyperresponsiveness. Eur J Respir Dis 1983;64, suppl 128:206-11.

12 Medical Research Council. Definition and classification of chronic bronchitis for clinical and epidemiological purposes. Lancet 1965; i:775-9.

13 DuBois AB, Botelho SY, Comroe JH. A new method for measuring airway resistance in man using a body plethysmograph: values in normal subjects and patients with respiratory disease. $J$ Clin Invest 1956;35:327-35.

14 Hargreave FE, Ryan G, Thomson NC, et al. Bronchial responsiveness to histamine or methacholine in asthma: measurement and clinical significance. $J$ Allergy Clin Immunol 1981;63:347-55.

15 Roberts JA, Raeburn D, Rodger IW, Thomson NC. Comparison of in vivo airway responsiveness and in vitro smooth muscle sensitivity to methacholine in man. Thorax 1984;39:837-43.

16 Ogilvie CM, Forster RE, Blakemore WS, Morton JW. A standardised breath holding technique for the clinical measurement of the diffusing capacity of the lung for carbon monoxide. J Clin Invest 1957;36:1-7.

17 Cotes JE. Lung function principles and application in medicine: 4th ed. Oxford: Blackwell Scientific Publications, 1975.

18 Malo JL, Filiatrault S, Martin RR. Bronchial responsiveness to inhaled methacholine in young asymptomatic smokers. J Appl Physiol 1982;52:1464-72.

19 Cockcroft DW, Berscheid BA, Murdock KY. Bronchial response to inhaled histamine in asymptomatic young smokers. Eur J Respir Dis 1983;64:207-11.

20 Ramsdell JW, Nachtwey FJ, Moser KM. Bronchial hyperreactivity in chronic obstructive bronchitis. Am Rev Respir Dis 1982;126:829-32.

21 Bahous J, Cartier A, Ouimet G, Pineau L, Malo JL.
Non-allergic bronchial hyperexcitability in chronic bronchitis. Am Rev Respir 1984;129:216-20.

22 Gerrard JW, Cockcroft DW, Dosman JA. Increased non-specific bronchial reactivity in cigarette smokers with normal lung function. Am Rev Respir Dis 1980; 122:577-81.

23 Clark AJ. Acetylcholine and atrophine. J Physiol 1926;545-56.

24 Walters EH, O'Byrne PM, Fabbri LM, Nadel JA. A mechanism for airway hyperresponsiveness. Thorax 1984;39:706 (abstract).

25 Brink C, Grimaud C, Gullot C, Orehek J. The interaction between indomethacin and contractile agents on human isolated bronchial chains. $\mathrm{Br} J$ Pharmacol 1980;69:383-8

26 Thomson NC, O'Byrne PM, Hargreave FE. Prolonged asthmatic response to inhaled methacholine. $J$ Allergy Clin Immunol 1983;71:357-62.

27 Vincenc KS, Black JL, Yan K, Armour CL, Donnelly PD, Woolcock AJ. Comparison of in vivo and in vitro responses to histamine in human airways. Am Rev Respir Dis 1983;128:875-9.

28 Juniper EF, Frith PA, Dunnett C, Cockcroft DW, Hargreave FE. Reproducibility and comparison of responses to histamine and methacholine. Thorax 1978; 33: 705-10.

29 Thomson NC, Roberts R, Bandouvakis J, Newball H, Hargreave FE. Comparison of bronchial responses to prostaglandin $\mathrm{F}_{2 \alpha}$ and methacholine. $J$ Allergy Clin Immunol 1981;68:392-8.

30 O'Byrne PM, Ryan G, Morris M, et al. Asthma induced by cold air and its relationship to nonspecific bronchial responsiveness to methacholine. $A m R e v$ Respir Dis 1982;125:281-5.

31 Anderton RC, Cuff MT, Frith PA, et al. Bronchial responsiveness to inhaled histamine and exercise. $J$ Allergy Clin Immunol 1979;63:315-20.

32 Dahlen SE, Hanson G, Hedqvist P, Björck T, Granstom $E$, Dahlen B. Allergen challenge of lung tissue from asthmatics elicits bronchial contraction that correlates with the release of leukotrienes $\mathrm{C}_{4}, \mathrm{D}_{4}$, and $\mathrm{E}_{4}$,. Proc Natl Acad Sci USA 1983;80:1712-6.

33 Paterson JW, Lulich KM, Goldie RG. The role of $\beta$-adrenoceptors in bronchial hyperreactivity. In: Morley J, ed. Bronchial hyperreactivity. London: Academic Press, 1982.

34 Schellenberg RR, Foster A. Human asthmatic lung tissue responses in vitro. J Allergy Clin Immunol 1984;73: 149. 